\section{Editorial}

Check for updates

\section{OPEN ACCESS}

Received: Feb 27, 2019

Accepted: Feb 27, 2019

Address for Correspondence:

Beom Sun Chung, MD

Department of Anatomy, Ajou University

School of Medicine, 164 World Cup-ro,

Yeongtong-gu, Suwon 16499,

Republic of Korea.

E-mail: bschung@ajou.ac.kr

(c) 2019 The Korean Academy of Medical

Sciences.

This is an Open Access article distributed under the terms of the Creative Commons Attribution Non-Commercial License (https:// creativecommons.org/licenses/by-nc/4.0/) which permits unrestricted non-commercial use, distribution, and reproduction in any medium, provided the original work is properly cited.

ORCID iDs

Beom Sun Chung (iD)

https://orcid.org/0000-0002-3644-9120

Disclosure

The author has no potential conflicts of interest to disclose.

\title{
Three-dimensional (3D) Models of Monkey and Human
}

\author{
Beom Sun Chung (D) \\ Department of Anatomy, Ajou University School of Medicine, Suwon, Korea \\ - See the article "Rise of the Visible Monkey: Sectioned Images of Rhesus Monkey" \\ in volume 34 , number 8 , e66.
}

Three-dimensional (3D) models of monkey and human

Why did we reconstruct $3 \mathrm{D}$ models of monkey and human?

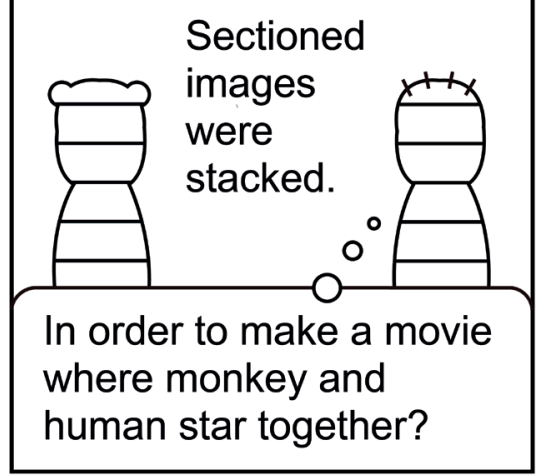

Actual experiment can be done with monkey $(C)$ observing animal ethics,
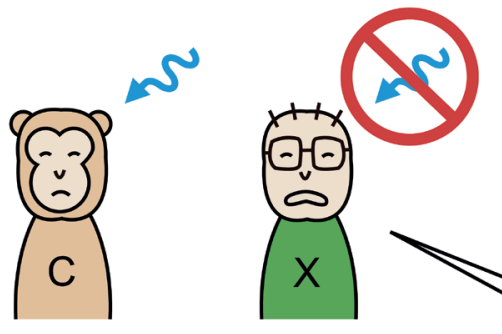

while that cannot be done with human $(X)$.
Virtual experiment can be done with 3D model of monkey (A) and that of human (B).
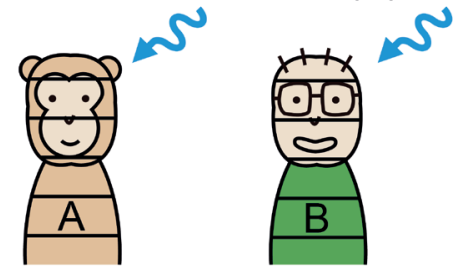

For example, effect of electromagnetic wave can be assessed.

As intended, result of actual experiment with human $(\mathrm{X})$ is predictable.

\begin{tabular}{|c|c|c|}
\hline & Monkey & Human \\
\hline Virtual & $\mathrm{A}$ & $\mathrm{B}$ \\
\hline Actual & $\mathrm{C}$ & $\mathrm{X}$ \\
\hline \multicolumn{3}{|c|}{$\mathrm{A}: \mathrm{B}=\mathrm{C}: \mathrm{X}$} \\
\hline
\end{tabular}

